\title{
Research on the water environment capacity of Qingyi River (Xuchang Section) with GIS technology
}

\author{
Li Wang ${ }^{1}$, Luji $\mathrm{Yu}^{2}$, Chunxiao $\mathrm{Liu}^{2}$, Nan Sun ${ }^{3}$ and Minquan Feng ${ }^{1, *}$ \\ ${ }^{1}$ State Key Laboratory Base of Eco-Hydraulic Engineering in Arid Area, Xi'an University of Technology, Xi'an, Shanxi, China \\ ${ }^{2}$ College of Water Conservancy \& Environmental Engineering, Zhengzhou University, Zhengzhou, Henan, China \\ ${ }^{3}$ Faculty of Chemistry Water Science, University Duisburg-Essen, Essen, Germany \\ Corresponding Email: mqfeng@xaut.edu.cn
}

\begin{abstract}
Water environment capacity calculation is the foundation of basin environment management. Due to lack of basic materials and data, the water environment capacity in small basin was not massively researched with appropriate calculating method. This paper mentioned a water capacity calculating method suitable for environment management. The method was based on the study of Xuchang Section of Qingyi River and described with details as follows: Xuchang Section was divided into four control units with GIS technology. The river pollution loads of non-point source pollutants from farmland runoff, rural life, livestock and poultry were calculated with the in-site and statistical data of pollution resource. Meanwhile the calculated river pollution loads of non-point / point source pollutants were statistically analyzed on the basis of control units. Then a water quality module was tested and verified, in which the predicted value tallied with the measured value. The parameter of this water quality module corresponds to the in-site data within relative error $\pm 14 \%$. This module was used to estimate and calculate water environment capacity. With this module the available water environment capacity of each control unit and pollutant reduction amount can be earned through deducting the river pollutant load of point pollutant. The results showed that the utilized method in this paper can satisfy the requirement for the calculating accuracy of small basin water environment capacity.
\end{abstract}

Keywords. Water environment capacity, geographic information system(GIS), non-point source pollutant (NSP), small basin

\section{Introduction}

Water environment capacity is a nature resource which exists objectively and also defines as a maximal permissible quantity of pollutants. It satisfies the requirement for particular water quality in a given water body with a target flowrate [1]. The utilization of water environment capacity has already become the scientific basis of China's water quality management and is also the theoretical basis of environmental policy such as capacity control, emission trading and permit system of pollution discharged [2]. China led on to many studies on water environment along with stricter and stricter control system of total emission [3-11]. Generally, most of the researches aim on rivers of big basins and important lake reservoirs, which can be deeply studied with professional software, since many monitoring sections of aquatic environmental quality and hydrological stations exist in those areas and a large amount of basic materials and data can be supplied. Small basins lack in hydrological materials and basic data to research on water environment capacity, therefore there was no suitable method to calculate water environment capacity of small basins. The calculation of water environment capacity in small basins should be more frequently considered to serve the development of the social economy, with the refinement of water environment protection. Recently the total pollutant control focuses mainly on point source pollutant, in contrast the non-point source pollutant has not been valued. The total pollutant control of point and non-point source pollutant used in many years is just starting in China [12]. Due to lack of data, the data of non-point source pollutant cannot be utilized to calculate water environment capacity. Therefore Li, Jake [13] preliminarily proposed a total pollutant control model with considering the effect of non-point source pollutants, and it was practically verified in Xi'an Section of Weihe River. Zhang, Likun [14] monitored the Ashi small river basin mainly with area pollution sources and calculated their environment capacities. Ji, Dingyu [15] researched on a small basin, Huangla Stream of the hilly area in Sichuan, and calculated river pollution load of non-pollutant resources according to rural life pollution, livestock pollution, chemical fertilizer and pesticide pollution. Another difficulty calculating water environment capacity is to determine the designed flowrate [16], so it can only be roughly calculated with the statistics data of water pollutant discharge amount.

This paper focuses on calculating water environment capacity of small basin by GIS technology [17], basing on study of Qingyi River (Xuchang Section). COD values from each control unit and available environment capacity of ammoniacal nitrogen were earned with considering the effect of non-point pollution resource from each aquatic and terrestrial control 
unit. This method enhanced the accuracy of water environment capacity and supplied environment protecting department the scientific basis to manage and control the total pollution load in small basin.

\section{Material and Methods}

Study Area. Xuchang Section of Qingyi River as the research target, belongs to the Huai River basin and is the largest and significant tributary of Shaying River (see Figure 1.) Xuchang Section of Qingyi River with length 79km has basin area $1585 \mathrm{~km}^{2}$. The average annual precipitation adds up to $671.1-736.0 \mathrm{~mm}$. Qingyi River is regarded as the main water body in the function of flood protection, flood drainage, waste drainage and landscape water. It is mainly influenced by industrial wastewater and urban wastewater.

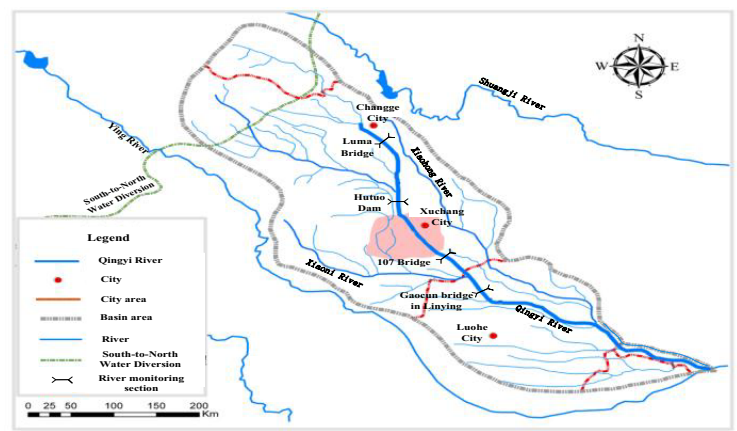

Fig. 1. Schematic diagram of scope of the study.

Research method. 1) Water quality model: The water quality of Qingyi River can be simulated with one dimensional model. To describe the steady decay law with one - dimensional model, assumes that water body keeps also the steady status under pollution and local hydrological conditions(the pollutant concentration in water body doesn't change with time.), moreover the effect of longitudinal diffusion is also ignored. The differential equation formulates:

$$
u \frac{\partial C}{\partial x}=-K C
$$

Under the initial condition $C=C_{0}$, equation 1 is converted:

$$
\begin{aligned}
C_{X} & =C_{0} \cdot e^{-k x / u} . \\
C_{0} & =\frac{\left(Q C_{1}+q C_{2}\right)}{(Q+q)} .
\end{aligned}
$$

$C_{X}$ : Calculated pollutant concentration in a certain section $[\mathrm{mg} / \mathrm{L}] ; C_{0}:$ Pollutant concentration in initial section $[\mathrm{mg} / \mathrm{L}] ; K$ : Pollutant degradation coefficient $\left[\mathrm{d}^{-1}\right] ; X:$ River length in a certain section $[\mathrm{km}] ; u$ : average flowrate in a certain section $[\mathrm{m} / \mathrm{s}] ; C_{1}$ : Pollutant background concentration in river $[\mathrm{mg} / \mathrm{L}] ; C_{2}:$ Pollutant concentration of discharged wastewater $[\mathrm{mg} / \mathrm{L}] ; Q:$ River flowrate $\left[\mathrm{m}^{3} / \mathrm{s}\right] ; q$ : Discharged wastewater flow $\left[\mathrm{m}^{3} / \mathrm{s}\right]$

2) Calculating model of water environment capacity: Water environment capacity is calculated with one-dimensional model by trial-and-error method, which utilizes a dynamic water quality model. The used "River Water Environment Capacity Analysis System" (6th Edition) was developed by Li, Yunsheng (Department of Pollutant Prevention of ministry of Environmental Protection). The rate of small river sections, in which the calculated pollutant concentration reaches a standard value, is more than $60 \%$, so that it can ensure the accuracy of water environment capacity calculation.

\section{Results}

Aquatic and terrestrial range of control unit. Determining aquatic and terrestrial range of control unit is the basis to calculate water environment capacity[2]. According to water environment functions and water quality monitoring points, DEM was analyzed by hydrologic analysis tool (ArcGIS) to select river networks and to divide river basin, then to calculate the closed catchment area. The terrestrial catchment range of control unit is finally determined through the adjustment of river data by GPS (see table 1). 
Table 1: Water area and land area of control units

\begin{tabular}{|c|l|c|c|c|}
\hline $\begin{array}{c}\text { control } \\
\text { units }\end{array}$ & \multicolumn{1}{|c|}{$\begin{array}{c}\text { Control units } \\
\text { Starting--Terminals }\end{array}$} & $\begin{array}{c}\text { Length } \\
(\mathrm{km})\end{array}$ & $\begin{array}{c}\text { Catchment } \\
\text { Area }\left(\mathrm{km}^{2}\right.\end{array}$ & $\begin{array}{c}\text { Water quality in } \\
\text { functional area }\end{array}$ \\
\hline Qing-1 & Xuchang--Lumaqiao & 21.3 & 193.2 & IV \\
\hline Qing-2 & Lumaqiao--Hutuozha & 7.7 & 358.5 & IV \\
\hline Qing-3 & $\begin{array}{l}\text { Hutuozha-— } \\
\text { Dongchengqu }\end{array}$ & 12.9 & 65.5 & IV \\
\hline Qing-4 & $\begin{array}{l}\text { Dongchengqu-— } \\
\text { Linyinggaoqiao }\end{array}$ & 11.6 & 486.2 & \\
\hline
\end{tabular}

Pollutant load in various pollution emission sites. The data of calculating water environment capacity of surface water comes from general national pollution resource investigation in 2007, in addition the new data of 2010 contributed also to the calculation. The data of COD and $\mathrm{NH}_{3}-\mathrm{N}$ discharge were statistically arranged according to industry, agriculture and life activities (see Figure.2 and 3).

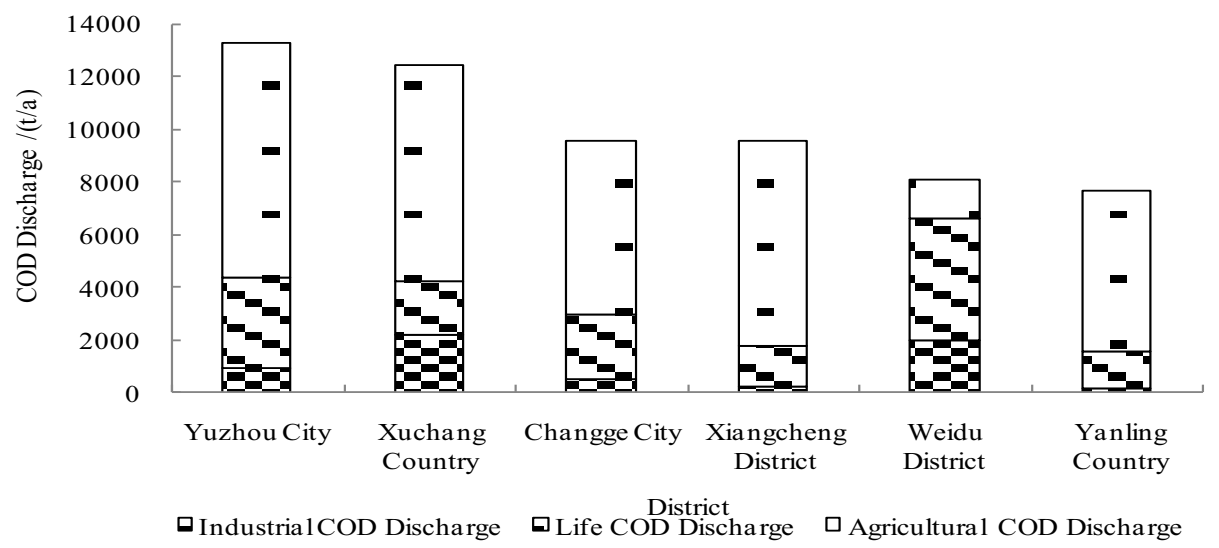

Fig. 2.Consist of COD discharge in county and district of XuChang.

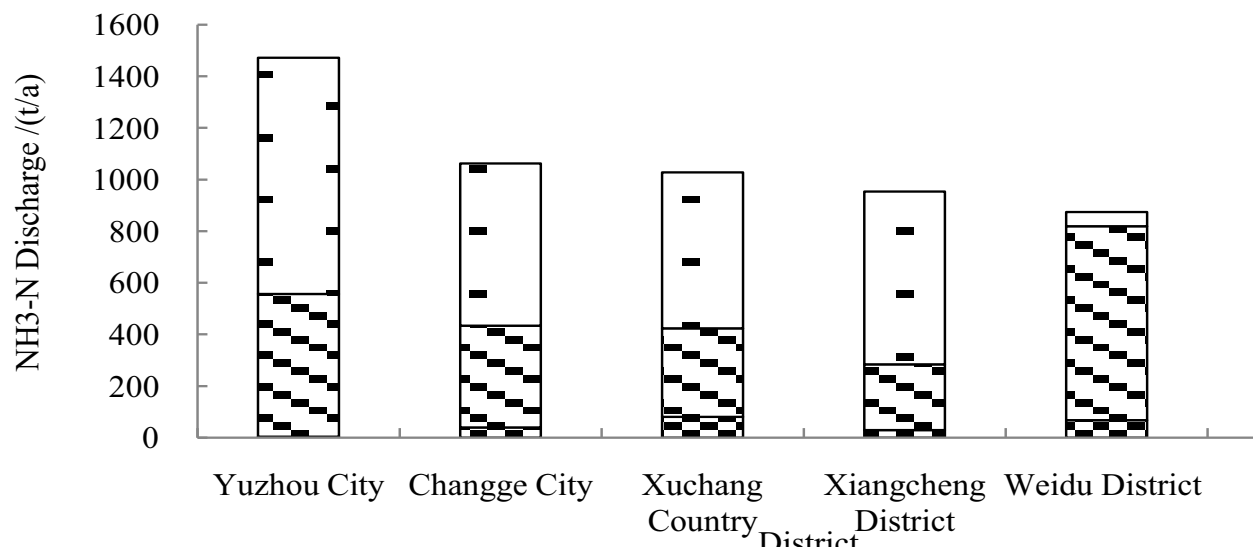

Fig. 3. Consist of $\mathrm{NH}_{3}-\mathrm{N}$ discharge in county and district of XuChang.

Point and non-point source pollutant load.The investigation of point and non-point source pollutant depends on connection of pollution source, pollution discharge outlets and contaminated water body. The pollution discharge outlets are navigated by GPS in order to determine pollutant discharge and the main pollution discharge outlets, which influence the water quality in functional regions. River load of point and non-point source pollutants is statistically analyzed at the point of control units (see table 2). Table 3 shows the pollutant loads calculated separately according to point and non-point source pollutant.

Table 2. Loads of point pollutant sources in control units.

\begin{tabular}{|c|c|c|c|}
\hline Control & Wastewater Load & COD Load & $\mathrm{NH}_{3}-\mathrm{N} \mathrm{Load}$ \\
\hline
\end{tabular}




\begin{tabular}{|c|c|c|c|}
\hline units & $(10$ thousand $\mathrm{t} / \mathrm{a})$ & $(\mathrm{t} / \mathrm{a})$ & $(\mathrm{t} / \mathrm{a})$ \\
\hline Qing 1 & 1700.9 & 1994.5 & 262.2 \\
\hline Qing 2 & 439.2 & 176.2 & 14.2 \\
\hline Qing 3 & 6816.6 & 7231.9 & 525.7 \\
\hline Qing 4 & 6.8 & 10.5 & 0.4 \\
\hline Total & 8963.5 & 9413.1 & 802.5 \\
\hline
\end{tabular}

Table 3. Loads of non-point pollutant sources in control units.

\begin{tabular}{|c|c|c|c|c|c|c|c|c|}
\hline \multirow{2}{*}{$\begin{array}{c}\text { Control } \\
\text { units }\end{array}$} & \multicolumn{2}{|c|}{ Agriculture $(\mathrm{kg} / \mathrm{a})$} & \multicolumn{2}{c|}{ Rural life $(\mathrm{kg} / \mathrm{a})$} & \multicolumn{2}{c|}{ Livestock $(\mathrm{kg} / \mathrm{a})$} & \multicolumn{2}{c|}{ Total $(\mathrm{kg} / \mathrm{a})$} \\
\cline { 2 - 9 } & $\mathrm{COD}$ & $\mathrm{NH}_{3}-\mathrm{N}$ & $\mathrm{COD}$ & $\mathrm{NH}_{3}-\mathrm{N}$ & $\mathrm{COD}$ & $\mathrm{NH}_{3}-\mathrm{N}$ & $\mathrm{COD}$ & $\mathrm{NH}_{3}-\mathrm{N}$ \\
\hline Qing 1 & $/$ & 550 & 84050 & 8050 & 154370 & 12210 & 238420 & 20810 \\
\hline Qing 2 & $/$ & 60 & 12160 & 1210 & 162450 & 11700 & 174610 & 12970 \\
\hline Qing 3 & $/$ & 110 & 0 & 0 & 74110 & 2650 & 74110 & 2760 \\
\hline Qing 4 & $/$ & 60 & 12160 & 1210 & 40610 & 2880 & 52770 & 4150 \\
\hline Total & & 780 & 108370 & 10470 & 431540 & 29440 & 539910 & 40690 \\
\hline
\end{tabular}

Determination and verification of water quality model parameter. $\mathrm{COD}$ and $\mathrm{NH}_{3}-\mathrm{N}$ degradation coefficient with $0.151 / \mathrm{d}$ and $0.181 / \mathrm{d}$ are the calculated coefficient resulting from the measurement between upper section in Maluqiao and lower section in Hutuozha. The monitoring data in November, December, January and February, 2009 were used to determine the initial concentration of upper boundary in model validation units. The hydrological parameter in low-water period are entered into the model to estimate the concentration of lower boundary with one-dimensional water quality model. From figure 4 and 5 the predicated value is corresponding with measured value (relative error $\pm 14 \%$ ). It can reflect the changes of practical value. Therefore the chosen model parameter are suitable for the state of Qingyi River.

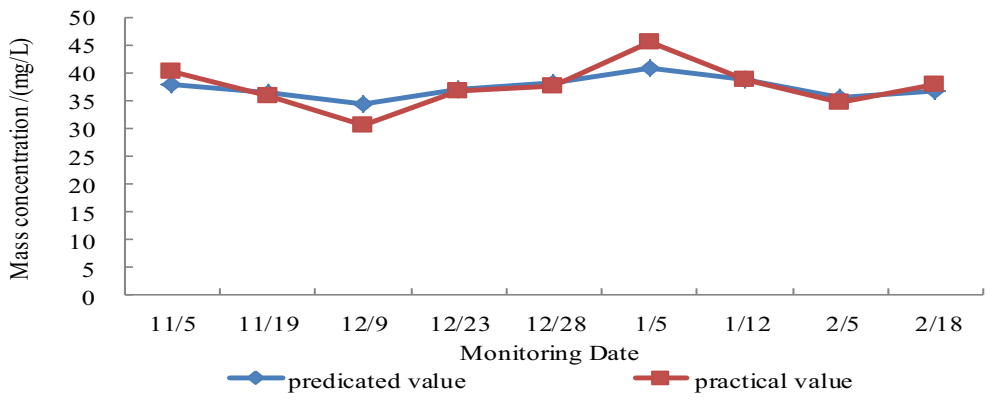

Fig. 4. Comparison of COD predicated and practicaldata at HuTuoZHA.

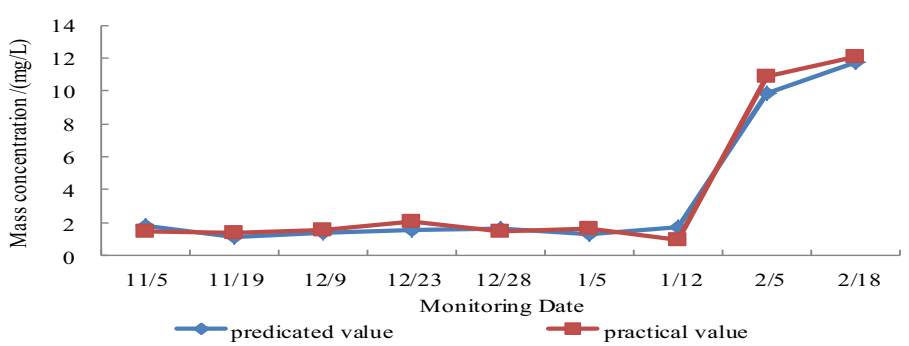

Fig. 5. Comparison of $\mathrm{NH}_{3}-\mathrm{N}$ predicated and practical data at hutuozha.

Water environment capacity calculating. The water quality model was at first verified through deducting non-point source pollutant load of each control units. Water environment capacity was calculated under the design conditions of driest months of recent 10 decade. The calculated available water environment capacities were shown in table 4. Meanwhile the results were earned with considering of $1.2 \mathrm{~m}^{3} / \mathrm{s}$ biological water transfer. The water environment capacity in Qingyi River was also calculated, ignoring the biological water transfer. 
Table 4. Water environmental capacity calculation results.

\begin{tabular}{|c|c|c|c|c|c|c|c|c|c|c|c|c|}
\hline River & $\begin{array}{c}\text { Contr } \\
\text { ol } \\
\text { units }\end{array}$ & $\begin{array}{c}\text { Distric } \\
\mathrm{t}\end{array}$ & $\begin{array}{l}\text { Av } \\
\text { wate } \\
\text { in th } \\
\text { mon } \\
\text { years }\end{array}$ & $\begin{array}{l}\text { ble } \\
\text { uality } \\
\text { Iriest } \\
\text { of } 10 \\
\text { t/a) }\end{array}$ & $\begin{array}{l}\text { Non- } \\
\text { water }\end{array}$ & $\begin{array}{l}\text { logic } \\
\text { nsfer } \\
\text { n }\end{array}$ & $\begin{array}{l}\text { Max. a } \\
\text { polluti } \\
\text { ( }\end{array}$ & $\begin{array}{l}\text { mitted } \\
\text { n load } \\
\text { l) }\end{array}$ & $\begin{array}{r}\operatorname{Pr} \\
\text { Pollut }\end{array}$ & $\begin{array}{l}\text { ent } \\
\text { n load } \\
\text { l) }\end{array}$ & & \\
\hline \multirow{5}{*}{$\begin{array}{l}\text { Qing } \\
\text { yi }\end{array}$} & & & COD & $\begin{array}{c}\mathrm{NH}_{3-} \\
\mathrm{N}\end{array}$ & COD & $\begin{array}{c}\mathrm{NH}_{3}- \\
\mathrm{N}\end{array}$ & COD & $\begin{array}{c}\mathrm{NH}_{3-}^{-} \\
\mathrm{N}\end{array}$ & COD & $\begin{array}{l}\mathrm{NH}_{3-} \\
\mathrm{N}\end{array}$ & COD & $\begin{array}{c}\mathrm{NH}_{3-}^{-} \\
\mathrm{N}\end{array}$ \\
\hline & Qing1 & $\begin{array}{l}\text { Chang } \\
\text { ge }\end{array}$ & $\begin{array}{c}427.5 \\
8\end{array}$ & $\begin{array}{c}33.1 \\
9\end{array}$ & $\begin{array}{c}427.5 \\
8\end{array}$ & $\begin{array}{c}33.1 \\
9\end{array}$ & $\begin{array}{c}567.2 \\
7\end{array}$ & $\begin{array}{c}44.0 \\
3\end{array}$ & $\begin{array}{c}2631.9 \\
8\end{array}$ & $\begin{array}{c}426.9 \\
5\end{array}$ & $\begin{array}{c}2064.7 \\
1\end{array}$ & $\begin{array}{c}382.9 \\
2\end{array}$ \\
\hline & Qing2 & $\begin{array}{c}\text { Xucha } \\
\text { ng }\end{array}$ & 5.39 & 2.03 & 5.39 & 2.03 & 6.32 & 2.38 & 205.64 & 17.50 & 199.32 & 15.12 \\
\hline & Qing3 & Weidu & $\begin{array}{c}2566 . \\
89 \\
\end{array}$ & $\begin{array}{c}193 . \\
24 \\
\end{array}$ & $\begin{array}{c}2112 . \\
89\end{array}$ & $\begin{array}{c}105 . \\
24 \\
\end{array}$ & $\begin{array}{c}3371 . \\
43\end{array}$ & $\begin{array}{c}264 . \\
14 \\
\end{array}$ & $\begin{array}{c}8980.5 \\
1 \\
\end{array}$ & $\begin{array}{c}1175 . \\
55\end{array}$ & $\begin{array}{c}5609.0 \\
8 \\
\end{array}$ & $\begin{array}{c}911.4 \\
1 \\
\end{array}$ \\
\hline & Qing4 & Weidu & $\begin{array}{c}1388 . \\
23\end{array}$ & $\begin{array}{c}72.8 \\
5\end{array}$ & $\begin{array}{c}1272 . \\
23\end{array}$ & $\begin{array}{c}66.8 \\
5\end{array}$ & $\begin{array}{c}2191 . \\
94\end{array}$ & $\begin{array}{c}121 . \\
42\end{array}$ & 15.00 & 0.87 & $\begin{array}{c}-2176 . \\
94\end{array}$ & $\begin{array}{c}-120.5 \\
5\end{array}$ \\
\hline \multicolumn{3}{|c|}{ Total } & $\begin{array}{c}4388 . \\
09\end{array}$ & $\begin{array}{c}301 . \\
31\end{array}$ & $\begin{array}{c}3818 . \\
10\end{array}$ & $\begin{array}{c}207 . \\
31\end{array}$ & $\begin{array}{c}6136 . \\
96\end{array}$ & $\begin{array}{c}431 . \\
97\end{array}$ & $\begin{array}{c}11833 . \\
13\end{array}$ & $\begin{array}{c}1620 . \\
87\end{array}$ & $\begin{array}{c}5696.1 \\
7\end{array}$ & $\begin{array}{c}1188 . \\
90\end{array}$ \\
\hline
\end{tabular}

\section{Discussion}

According to the monitoring-data (2011) of processing profile in Qingyi River, COD rises but $\mathrm{NH}_{3}-\mathrm{N}$ decreases in Xuchang Section of Qingyi River. In 2009 the calculated concentrations of all sections in Qingyi River are higher than the standard value. $\mathrm{COD}$ and $\mathrm{NH}_{3}-\mathrm{N}$ concentrations gradually decrease according to the following sequence: high-water period, normal water period, low-water period. The concentrations in high-water and normal water period are lower than the average value. $\mathrm{COD}$ and $\mathrm{NH}_{3}-\mathrm{N}$ concentrations reach a maximum in high-water period, since the pollutants are diluted with high water load.

COD concentration rises gradually from upper reaches to lower reaches and the high COD load occurs in the middle and lower reaches of Qingyi River to lead to a heavy pollution in those regions. In contrast $\mathrm{NH}_{3}-\mathrm{N}$ concentration is higher in upper reaches than in lower reaches. This concentration change illustrates that the $\mathrm{NH}_{3}-\mathrm{N}$ load is higher in upper reaches.

The total carbon emission amounts to $60956.32 \mathrm{t}$ including centralized carbon emissions. The $64.85 \%$ of the total emission comes from agriculture, which takes up a large slice. Life activities is the main COD emission source in Weidu District and it is the largest part with $57.09 \%$ of the total emission in this District. In contrast COD emission in the other five boroughs accounts for about $66 \%-82 \%$ and comes mostly from agriculture. However in Xuchang Country industrial COD emission takes up the largest part and reaches $2123.06 \mathrm{t} / \mathrm{a}$. The total $\mathrm{NH}_{3}-\mathrm{N}$ emission is $6189.04 \mathrm{t} / \mathrm{a}$ in the six boroughs (including centralized emission), in which agriculture is the largest emission source with $54.95 \%$. In Weidu District life activities is also the major COD emission source, taking up $86.04 \%$ of the total emission. In other five boroughs agricultural $\mathrm{NH}_{3}-\mathrm{N}$ emission with $54 \%$ - $71 \%$ occupies still the first place. At the point of the view of industrial $\mathrm{NH}_{3}-\mathrm{N}$ emission, Xuchang Country and Weidu District are considered particularly noteworthy, with the emission amount of $79.34 \mathrm{t} / \mathrm{a}$ and $66.66 \mathrm{t} / \mathrm{a}$.

The calculated result of water environment capacity indicates that $\mathrm{COD}$ and $\mathrm{NH}_{3}-\mathrm{N}$ emission at the other three control units doesn't reach the standard except at the fourth control unit. Therefore the emission at the other three control units should be reduced. Among these three control units the reduction maximum arises at the third control unit and amounts to $5609.08 \mathrm{t} / \mathrm{a}$ and $911.41 \mathrm{t} / \mathrm{a}$. Its emission maximum is attributed to the location of the third control unit, in which a large amount of domestic waste water and industrial waste water emit.

\section{Conclusion}

The river basin distribution graph was drawn with ArcGIS9.0 hydrological analysis. The river data were adjusted by onsite GPS location and were added in the graph. The finally gathered information were used to earn the catchment area of control units. The contour line graph was also used as an auxiliary tool for analysis.

The pollutant data came from point source online monitoring data and national pollution investigation data. The point source pollution was investigated according pollution resource, pollution discharge and the corresponding aquatic and terrestrial relationship of control units. The pollution drain outlet was located by GPS to determine the main pollution drain outlet which influences the river quality and its pollution discharge. The point Pollution discharge was statistically analyzed by control units. Non-point source pollutant includes rural life pollutant, livestock pollutant and farmland runoff pollutant. To get the discharge load of the rural life pollutant, pollutant load was calculated with recommended value of pollutant coefficient by national water environment capacity verification manual. The earned discharge load was distributed into the rivers according to the distribution principle: the emitted pollutant load is distributed at the point of view of resident sites and basin area of control units. 
The representative river basin was select to verify the water quality model with water quality monitoring data in driest water period. The measured value had a relative low error with the predicted value. The verified water quality model was used to calculate the available water environment capacity of control units through the removal of non-point source pollutant load. Conclusion showed: the emission differences of aquatic and terrestrial control units were used to earn a practical calculated value with GIS technology, considering with the effect of non-point pollutant. Meanwhile the pollutant load was separately calculated to make the environment more scientific.

\section{Acknowledgment}

This work was supported by Major Science \&Technology Program for Water Pollution Control and Treatment (2015ZX07204-002-005)

\section{References}

1. China's environmental sarft. 2004. The technical review key point of the surface water environmental capacity for approval.

2. China's environmental sarft. 2003. The technical review key point of the surface water environmental capacity for approval.

3. Y. Zhou, X.D. Zhou and M.Q. Feng: Journal of Xi'an University of Technology Vol. 27 (2011), p. 7-11.

4. G. Zhou, K. Lei, G. Fu and G.J. Mao: Journal of Hydraulic Engineering Vol. 45 (2014), p. 227-234+242.

5. Y. Zhang, Y. Liu and X.G. Li: Technology of Soil and Water Conservation. 3 (2015), p. 23-25.

6. H. Ma. 2006. Study of Water Environmental Capacity of Songhua River along Harbin City.Harbin:Harbin institute of thchnolology.

7. J.G. Lu, X. Zhong, Y. Liu and H. Wang: Water Resources and Power Vol. 33 (2015), p. 51-54.

8. S.T. Cheng, Y.C. Qian and H.J. Zhang: Acta Scientiae Circumstantiae Vol. 33 (2013), p. 2848-2855

9. S.F. Ge. 2012. Study on water environmental capacity of Liaohe River in Jilinprovince. Changchun:Jilin University.

10. Z.L. Huang, Y.L. LI, J.X. LI and Y.C. Chen: Journal of Hydraulic Engineering. 3 (2004), p. 7-14.

11. Y.Y. Liang. 2004. Research on the Water Environmental Capacity in Bengbu Urban Section of Huai River.Hefei: Hefei University of technology.

12. L.M. Zhang, Y. Liu, W.H. Sun and B. Bian: Journal of Lake Sciences Vol. 21 (2009) , p. 502-508.

13. J.K. Li, J.J. Zhou, H.E. Li, M. Cai and L. Zhu: Journal of Xi' an University of Technology Vol. 28 (2012), p. $269-277$.

14. L.K. Zhang. 2014. Study on Water Pollutants Total Amount Control Technique in Ashi River Basin Based On Non-point Source Pollution Control.Beijing: Chinese Research Academy of Environmental Sciences.

15. D.Y. Ji, Q.G. Wang, H.Y. She, D.R. Wang and X. Zhang: Journal of Water Resources \& Water Engineering Vol. 22 (2011), p. 81-84.

16. Y.X. Zhao, M. Xu and Y. Chen: Environmental Pollution \& Control Vol. 37 (2015), p. 69-75.

17. C.X. Liu, L. Wang and P. Zhang: Journal of Anhui Agricultural Sciences Vol. 40 (2012), p. 2531-2533. 